\title{
ЛЮМІНЕСЦЕНТНІ ВЛАСТИВОСТІ ПРИПОВЕРХНЕВИХ НАПІВПРОВІДНИКОВИХ ШАРІВ ТА КВАНТОВИХ НАДІРАТОК
}

\author{
В.Г. ЛИТОВЧЕНКО, Д.В. КОРБУТЯК
}

УДК 621.315.592

(C) 2011

Інститут фізики напівпровідників ім. В.Є. Лашкарьова НАН України

(Просп. Науки, 41, Київ 03680; e-mail: lvg@ rsp. krev. ua,kdv45@ rsp. krev.ua)

\begin{abstract}
Наведено нові результати люмінесцентних досліджень квантових надграток (HГ) GaAs/AlAs I-го та II-го роду, а також меж поділу гетероструктур GaAs/AlAs з використанням імпульсних фемтосекундних джерел збудження. Проаналізовано особливості кінетики фотолюмінесценції НГ GaAs/AlAs 3 різними ширинами квантових ям (GaAs) та бар'єрів (AlAs). При високих рівнях збудження у квазіпрямозонних НГ формується електронно-діркова плазма, концентрація носіїв заряду в якій більш ніж на порядок перевищує відповідне значення для об'ємних кристалів GaAs. Дослідження спектрів спонтанного та вимушеного випромінювання електронно-діркової плазми в HI GaAs/AlAs дозволило розрахувати спектри коефіцієнтів оптичного підсилення залежно від густини оптичної накачки в області нелінійних ефектів.
\end{abstract}

\section{1. Вступ}

Розвиток сучасної інтегральної електроніки і оптоелектроніки стимулює широкі дослідження різного типу двовимірних і квазідвовимірних ефектів, що протікають у просторово-обмежених шаруватих системах: на поверхні напівпровідників, межах поділу гетероструктур та у квантових надгратках [1-7]. При цьому важливим є застосування високочутливої неруйнівної методики фотолюмінесценції (ФЛ) для дослідження фундаментальних характеристик вказаних систем. Принциповим є питання про формування і прояв в оптичних спектрах нерівноважної електронно-діркової плазми (ЕДП) на межах поділу шаруватих структур "діелектрик-напівпровідник" $[8,9]$ та у шаруватих напівпровідниках $[10,11]$. Для квазідвовимірної ЕДП очікується низка особливостей нелінійних оптичних ефектів, зумовлених великою концентрацією нерівноважних носіїв заряду порівня- но з тривимірною ЕДП при однакових умовах збудження, зокрема, процесів вимушеного випромінювання у поверхневих областях напівпровідників та в квантово-розмірних структурах з надтонкими шарами (квантових надгратках I і II типу). У даній роботі наведено результати люмінесцентних досліджень квантових HI GaAs/AlAs I i II типу та меж поділу гетероструктур GaAs/AlGaAs з використанням імпульсних (фемтосекундних) джерел збудження. Зокрема проаналізовано особливості кінетики ФЛ $\mathrm{HI} \mathrm{GaAs} / \mathrm{AlAs}$ з різними ширинами квантових ям (GaAs) та бар'єрів (AlAs). Експериментально виміряно та теоретично розраховано спектри оптичного підсилення (ОП) у квантових надгратках GaAs/AlGaAs.

\section{2. Затухання фотолюмінесценції в надгратках I типу}

Дослідження кінетики затухання ФЛ квантових надграток надає важливу інформацію про їх енергетичні спектри. Зокрема, актуальним є часовий інтервал $\Delta t=10^{-9}-10^{-12}$ с після збудження зразка лазерним імпульсом, протягом якого відбуваються зміни механізмів рекомбінації (участь легких і важких дірок, вільних і зв'язаних екситонів тощо).

Дослідження затухання ФЛ 3 використанням імпульсних лазерів з тривалістю імпульсів $\sim 10^{-13}$ с дозволяє встановити типи випромінювальних електронно-діркових переходів, часові характеристики того чи іншого механізму рекомбінації, розділення близьких за енергією піків, які відрізняються часами рекомбінації [12].

Типовий спектр прямозонної НГ складається 3 однієї вузької смуги ФЛ, зумовленої рекомбінацією 

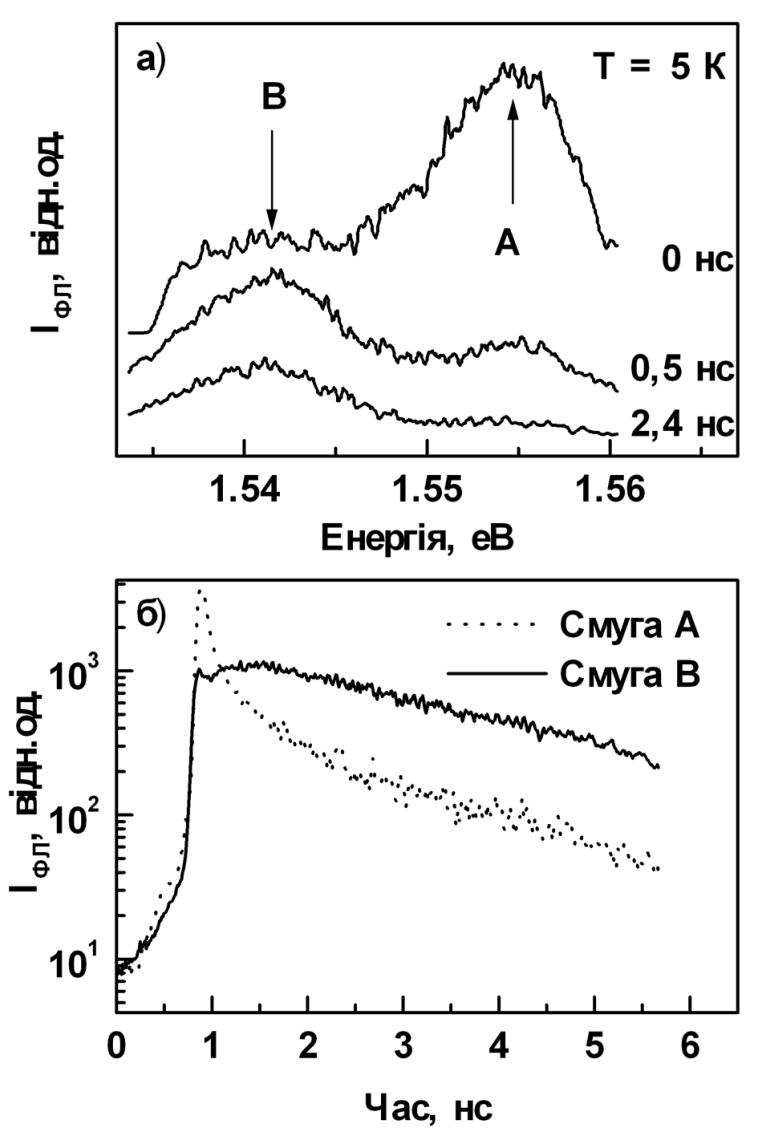

Рис. 1. Спектри ФЛ НГ 36/36 при $T=5 \mathrm{~K}$, отримані при різних часових затримках після збуджуючого імпульсу $(a)$; часові залежності інтенсивності ФЛ смуг А та В (б)

важких екситонів (електрон-важка дірка), локалізованих у шарах GaAs. Однак у деяких дослідженнях спостерігалась додаткова смуга ФЛ, яка була приписана легким екситонам, що складаються з електронів та легких дірок.

На рис. 1 зображено спектри ФЛ НГ GaAs/AlAs 36/36 (36/36 - кількість моношарів GaAs і AlAs відповідно), отримані в різні моменти часу після збуджуючого імпульсу лазера. Спектр ФЛ складається 3 двох ліній, які позначено на рис. 1, $a$, відповідно, А і В $з$ енергіями максимумів 1,555 i 1,541 еВ. Енергетична відстань між ними 14 меВ є близькою до розрахованого розщеплення підзон важких і легких дірок (18 меВ). Однак при розрахунках не враховано різницю в енергії зв'язку важких і легких екситонів, яка становить $\sim 2$ меВ для даних товщин ям.

Кінетика ліній А і В є різною (див. рис. 1,б). У той час, як лінія А при $5 \mathrm{~K}$ демонструє біекспоненційне затухання зі сталими часу $\sim 100$ пс і $\sim 1,7$ нс, інтенсивність лінії В спочатку росте зі сталою часу

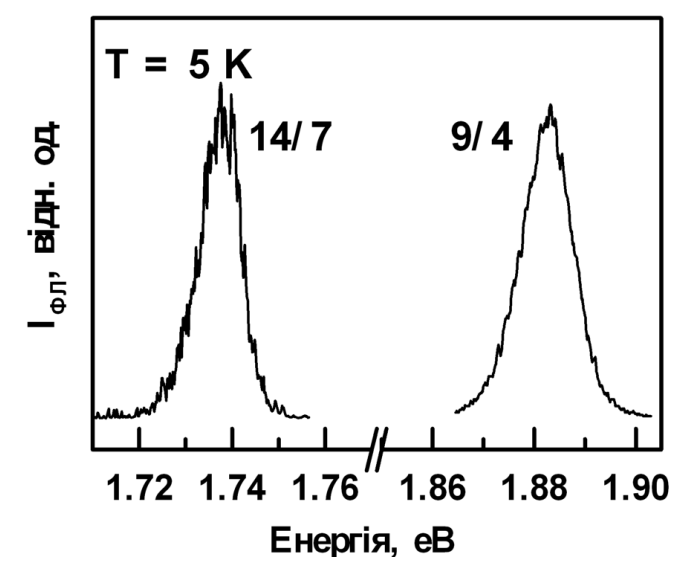

Рис. 2. Спектри ФЛ НГ $14 / 7$ та $9 / 4$ при $T=5$ К. Спектри нормовані по відношенню до їх максимумів

$\sim 230$ пс, а потім спадає зі сталою часу $\sim 2,7$ нс. Початкове згасання смуги А і одночасне зростання інтенсивності смуги В може бути пояснене переходом від легких до важких екситонів.

Довгочасові компоненти відповідають часу життя двох типів екситонів. Їхне зростання з підвищенням температури дозволяє зробити висновок, що спостережувані екситони є вільними.

Розглянемо далі кінетику ФЛ зразків з меншими товщинами квантових шарів (НГ $14 / 7$ та 9/4). Обидві НГ також належать до прямозонних НГ I типу. Спектри ФЛ цих НГ, зображені на рис. 2, складаються з однієї вузької лінії, зумовленої рекомбінацією екситонів (електрон - важка дірка), локалізованих у шарах арсеніду галію.

Зазначимо, що ширина квантової ями НГ 9/4 менша за критичну, при якій відбувається перехід до квазіпрямозонних НГ II типу (12 моношарів). Однак менша ширина бар'єра, порівняно 3 шириною ями, зумовлює прямозонність даної НГ з мінімумом зони провідності, локалізованим у Г-точці GaAs.

Дослідження спектрів ФЛ з часовим розділенням НГ 9/4 показали, що у всьому інтервалі досліджуваних температур (5-100 K) затухання максимуму ФЛ описується однією експонентою (рис. 3), що свідчить про локалізацію екситонів навіть при досить високих температурах. Привертає увагу досить сильна температурна залежність часу затухання ФЛ НГ $9 / 4$ на відміну від більш широкоямних зразків: при низьких температурах $(T>$ $30 \mathrm{~K}$ ) час затухання практично не змінюеться, а підвищення температури $330 \mathrm{~K}$ до $80 \mathrm{~K}$ приводить до зменшення часу затухання $3 \sim 200$ пс до $\sim 30$ пс. 


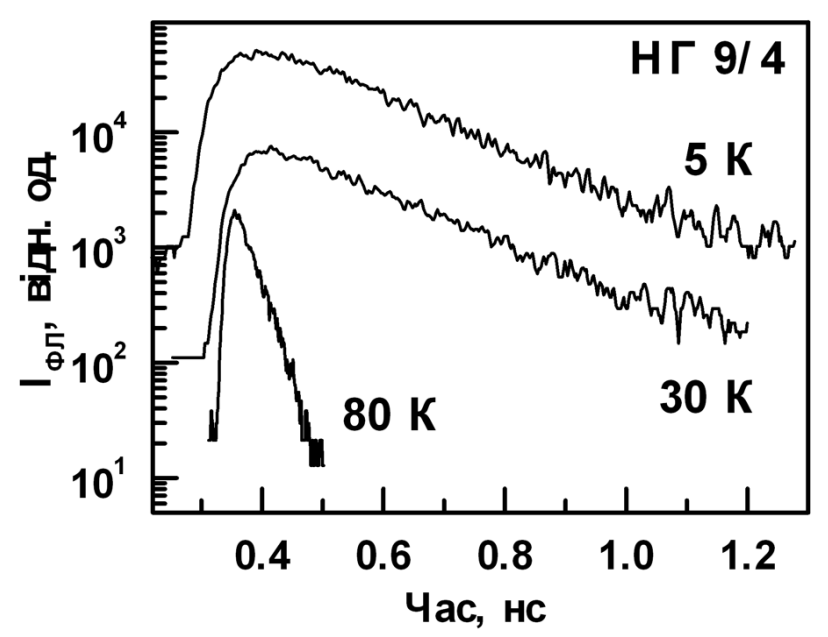

Рис. 3. Часові залежності інтенсивності максимуму ФЛ НГ 9/4 при $T=5 \mathrm{~K}, T=30 \mathrm{~K}, T=80 \mathrm{~K}$

Отримані результати можна підсумувати так. У прямозонних НГ, ширина ями в яких порівняна з радіусом екситона (як в НГ 36/36), у спектрах ФЛ спостерігаються дві смуги вільних екситонів, що формуються за участі важких і легких дірок. В НГ, ширина ями яких в $\sim 1,5$ раза менша від радіуса екситона, який таким чином виявляється "затиснутим" стінками ями, вільні екситони швидко (протягом $\sim 150$ пс) локалізуються на гетеромежах GaAsAlAs. У HГ 14/7 з ще тоншими шарами квантової ями ( 0,4 радіуса екситона) випромінювання при низьких температурах зумовлене зв'язаними екситонами, часткова делокалізація яких починається тільки при підвищенні температури ( $T \geq 80 \mathrm{~K})$. У прямозонних HГ GaAs/AlAs з надтонкими шарами (НГ 9/4) випромінювання локалізованих екситонів спостерігається у всьому досліджуваному інтервалі температур.

\section{3. Кінетика фотолюмінесценції короткоперіодних надграток GaAs/AlAs II типу}

У даному підрозділі описано результати досліджень спектрів фотолюмінесценції 3 часовою розгорткою (ФЛЧР) двох НГ GaAs/AlAs другого типу. Один із зразків, НГ $5 / 5$, належить до квазіпрямозонних НГ, ФЛ яких зумовлена рекомбінацією просторово розділених екситонів, що складаються $3 X_{z}$ електронів бар'єра і важких дірок, локалізованих у шарі GaAs.

На рис. 4 зображено спектри ФЛЧР НГ 5/5, отримані при різних температурах та при нульовій часовій затримці після збудження. У температурному інтервалі $T=5-20 \mathrm{~K}$ спостерігається зсув максимуму ФЛ

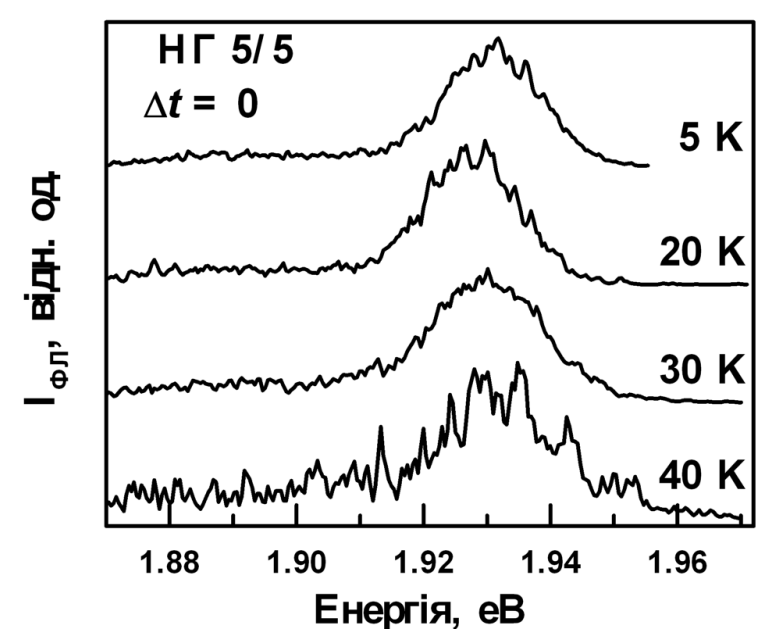

Рис. 4. Спектри ФЛЧР НГ 5/5 при нульовій затримці після збуджуючого імпульсу $(\Delta t=0)$ та при різних температурах

в довгохвильову область на $\sim 3$ меВ після часової затримки, величина якої залежить від температури і змінюється від $\sim 1$ мкс при $5 \mathrm{~K}$ до $\sim 100$ нс при $20 \mathrm{~K}$.

Наведені особливості спектра ФЛ НГ 5/5 є характерними для міждомішкової (донорно-акцепторної) рекомбінації. У цьому випадку енергія фотона $E_{\mathrm{ph}}$, що випромінюється, залежить від відстані між електроном і діркою за законом:

$E_{\mathrm{ph}}=E_{g}-\left(E_{\mathrm{D}}+E_{\mathrm{A}}\right)+\frac{e^{2}}{\varepsilon r_{n}}$,

де $E_{g}$ - ширина забороненої зони, $E_{\mathrm{D}}$ та $E_{\mathrm{A}}-$ енергії іонізації, відповідно, донорного та акцепторного центрів, $r_{n}$ - відстань між донором та акцептором, $\varepsilon-$ діелектрична стала.

Дійсно, зміщення смуги ФЛ у процесі затухання в довгохвильову область означає, що ближні пари зв'язаних електронів і дірок, які дають внесок у високоенергетичну область спектра, рекомбінують значно швидше, ніж віддалені пари, які для рекомбінації повинні протунелювати на більшу відстань, і дають внесок у низькоенергетичну область спектра. У нашому випадку центрами локалізації є флуктуації, викликані неоднорідністю гетеромеж. При цьому близько розташовані електрони і дірки внаслідок кулонівської взаємодії створюють специфічні локалізовані екситони. Зменшення часу рекомбінації таких екситонів із збільшенням температури викликане делокалізацією носіїв заряду i, відповідно, більш швидкою рекомбінацією (без процесу тунелювання).

3 іншого боку, вказана особливість може бути пояснена спектральною міграцією локалізованих екситонів, очевидно, шляхом випромінювання акустичних 


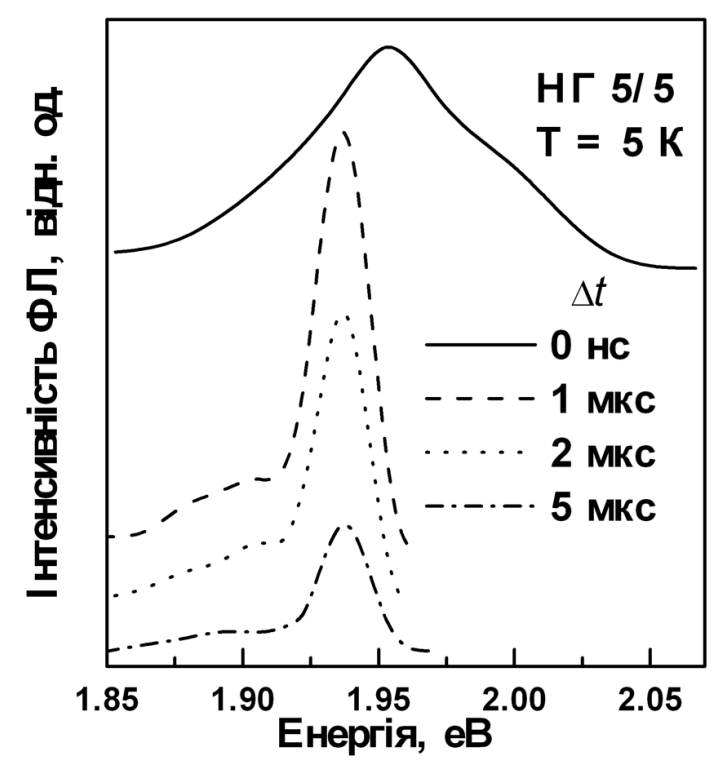

Рис. 5. Спектри ФЛ НГ 5/5, отримані при різних часових затримках у випадку високих рівнів збудження

фононів з більш мілких до глибших центрів локалізації.

Зсув енергії максимуму ФЛ зі зростанням температури відповідає температурній залежності ширини заборонених зон GaAs i AlAs, враховуючи те, що вони змінюються однаково [13]. При $T=30$ K спостерігається обернена ситуація (рис. 4): енергія максимуму спектра, що отриманий при нульовій затримці, на $\sim 2$ меВ більша, ніж відповідне значення при $20 \mathrm{~K}$. 3 часом, як і у попередніх випадках, також спостерігається червоний зсув максимуму. Однак у цьому випадку він становить $\sim 6-7$ меВ, що вдвічі більше, ніж при нижчих температурах. Це свідчить про те, що екситони є вільними в початковий момент часу після збудження, а з часом вони локалізуються на неоднорідностях гетеромеж. Величина червоного зсуву приблизно відповідає енергії локалізації екситонів. Характерно, що при $T=5-30 \mathrm{~K}$ форма кривих затухання ФЛ залежить від енергії детектування і змінюється від неекспоненційної на короткохвильовому крилі спектра до експоненційної на довгохвильовому крилі.

Кінетику ФЛ НГ 5/5 також досліджували при високих рівнях збудження з використанням імпульсного азотного лазера ( $P \sim 3 \mathrm{kB}$, півширина імпульсу 10 нс). Спектри ФЛ, отримані за таких умов, зображено на рис. 5 .

Привертає увагу той факт, що спочатку після збудження спостерігається широка смуга ФЛ $\left(E_{\max }=1,951 \mathrm{eB}\right)$ з півшириною $H \cong 43 \mathrm{меB}$, яка про-

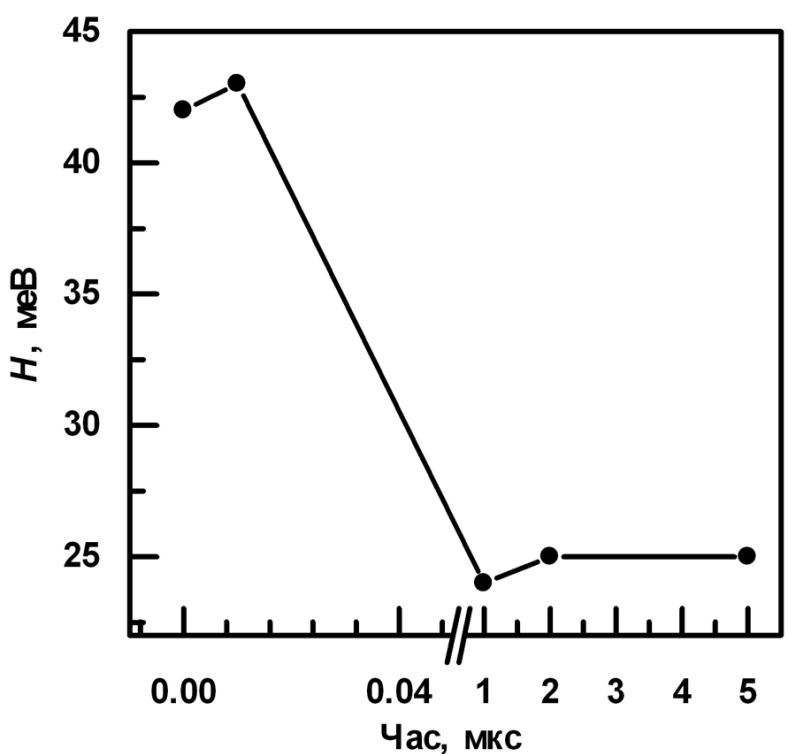

Рис. 6. Часові залежності півширини $H$ нуль-фононної лінії ФЛ НГ $5 / 5$ при високих рівнях збудження. $T=5 \mathrm{~K}$

тягом $\sim 10$ нс звужується до значення $H \cong 15 \mathrm{меВ}$ і зміщується в довгохвильову область на $\sim 20$ меВ. Надалі ї̈ енергетичне положення і півширина залишаються незмінними протягом всього часу гасіння смуги. Часові залежності значення півширини нульфононної лінії ФЛ зображено на рис. 6.

Вказані особливості ФЛ при високих рівнях збудження в НГ $5 / 5$ свідчать про такий характер рекомбінаційних процесів. Збуджені лазерним імпульсом нерівноважні електрони і дірки, термалізуючись у відповідних зонах, створюють вільні екситони. Однак велика густина екситонів приводить до формування в НГ нерівноважної електронно-діркової плазми, яка, рекомбінуючи, зумовлює появу короткохвильової смуги ФЛ. У процесі рекомбінації концентрація носіїв у плазмі зменшується, що підтверджується звуженням смуги ФЛ, і приблизно через 30 нс плазма практично зникає.

Нерівноважні електрони і дірки, які не встигли прорекомбінувати, створюють локалізовані $X_{z}-\Gamma$ екситони, які рекомбінують протягом $\sim 5$ мкс, що зумовлює появу довгочасової компоненти в кінетиці ФЛ досліджуваного зразка.

Параметр півширини плазмової смуги дозволяє визначити концентрацію вільних носіїв у сформованій потужним лазерним збудженням двовимірній електронно-дірковій плазмі:

$2 H \cong E_{\mathrm{F}_{n}}+E_{\mathrm{F}_{p}}=$ 


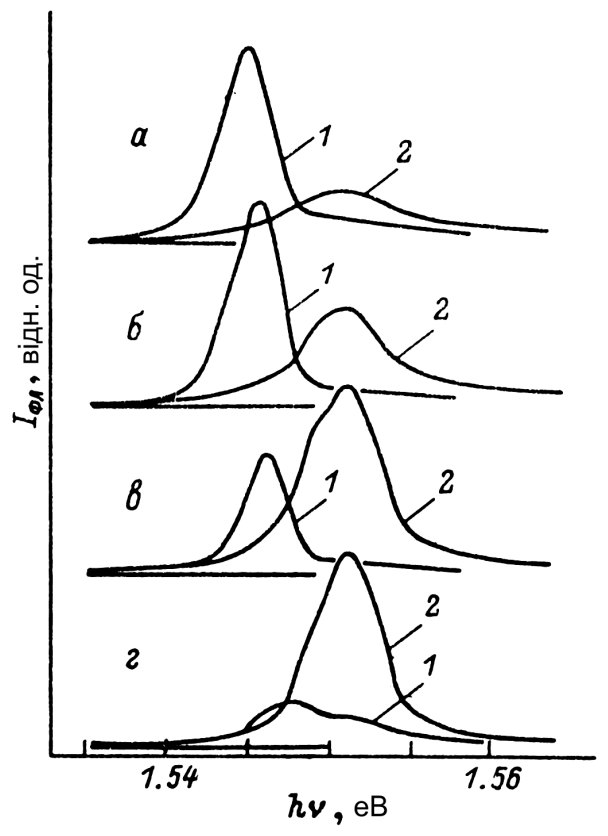

Рис. 7. Спектри стимульованого (1) і спонтанного (2) випромінювання надгратки $\mathrm{GaAs} / \mathrm{Al}_{0,35} \mathrm{Ga}_{0,65} \mathrm{As}$ при різних густинах збудження $\left(L_{0}=4 \mathrm{MBT} / \mathrm{cm}^{2}\right): a-L_{0}, \sigma-0,2 L_{0}$, в-0,05 $L_{0}$, г$0,02 L_{0}$

$=\frac{1}{2}\left(3 \pi^{2}\right)^{2 / 3} k_{0} T \hbar^{2}\left(\frac{1}{m_{e}}+\frac{1}{m_{p}}\right) n^{2 / 3}$

де $E_{\mathrm{F}_{n}}, E_{\mathrm{F}_{p}}-$ квазірівні Фермі для електронів і дірок, відповідно, $T$ - температура, $m_{e, p}$ - ефективні маси електронів та дірок, $n$ - концентрація носіїв у плазмі.

Отримана величина $n \sim 10^{18} \mathrm{~cm}^{-3}$ більше ніж на порядок перевищує відповідну концентрацію плазми в об'ємному GaAs $\left(3 \cdot 10^{16} \mathrm{~cm}^{-3}\right)$.

\section{4. Оптичне підсилення у квантових надгратках $\mathrm{GaAs} / \mathrm{Al}_{x} \mathrm{Ga}_{1-x} \mathrm{As}$}

Проведено дослідження спектрів оптичного підсилення у надгратках $\mathrm{GaAs} / \mathrm{Al}_{x} \mathrm{Ga}_{1-x} \mathrm{As}$ залежно від рівня оптичної накачки $L$.

Спектри коефіцієнта оптичного підсилення знаходили за методикою, описаною в [14]. Фотолюмінесценцію збуджували другою гармонікою лазера ЛТИПЧ-4 з активним елементом АИГ: $\mathrm{Nd}^{3+}$. Густина потужності збудження змінювалася в межах 0,08-4,0 $\mathrm{MBT} / \mathrm{cm}^{2}$.

На рис. 7 наведено спектри стимульованої (1) і спонтанної (2) ФЛ залежно від рівня збудження. Характерним $є$ досить низький поріг оптичної накачки $L_{\min }<0,08 \mathrm{MB} / \mathrm{cm}^{2}$, при якій виникає стимульоване випромінювання. Крім того, як видно з рис. 7, ма- ксимум стимульованого випромінювання зміщений у довгохвильову область порівняно з максимумом спонтанного випромінювання.

Спектри коефіцієнта оптичного підсилення розраховували із відношення інтенсивностей стимульованого і спонтанного випромінювання для відповідних довжин хвиль $\lambda$, отриманих при однакових рівнях збудження:

$\frac{I_{\text {стим }}}{I_{\text {спонт }}}=\frac{\exp (g l)-1}{g l}$,

де $g$ - коефіцієнт оптичного підсилення, $l$ - довжина смуги збудження (в умовах нашого експерименту $l=$ 100 мкм).

Розраховані таким способом спектри коефіцієнта оптичного підсилення для п'яти густин накачки наведено на рис. 8.

Розрахунок спектрів оптичного підсилення (ОП) в досліджуваних структурах проводили з урахуванням таких припущень:

1. Проведені оцінки енергетичного зазору між найнижчими рівнями електронної підсистеми для даного типу НГ з ширинами квантових ям $\sim 100 \AA$ при ширині бар'єрів $150 \AA$ дають значення $\sim 100 \mathrm{меВ,}$ що значно (в 6-10 разів) більше ширини експериментально отриманих смуг ОП навіть при максимально високих рівнях збудження. Тому при визначенні квазірівня Фермі в електронній підсистемі можна обмежитися врахуванням тільки найнижчої електронної підсистеми, а підзоною легких дірок можна знехтувати для даних конкретних умов експерименту.

2. При великих рівнях збудження короткохвильове розширення спектра ОП, як видно з рис. 7, стає слабким (на відміну від чітко вираженого довгохвильового розширення спектра ОП, пов'язаного з перенормуванням забороненої зони внаслідок багаточастинкових ефектів), що свідчить про розтікання електроннодіркової плазми [15].

3. Базовою моделлю для досліджуваної структури є модель прямих міжзонних переходів зі збереженням квазіімпульсу і з встановленням в електроннодірковій плазмі деякої ефективної температури внаслідок малості часів розсіювання носіїв заряду один на одному.

4. Форма спектрів ОП, характерною рисою яких є витягнуте довгохвильове крило, незважаючи на двовимірність випромінюючої електронно-діркової плазми, свідчить про розмиття кінцевих станів рекомбінуючих електронів і дірок. Тому узгодження розрахованих і експериментальних спектрів ОП проводилося в припущенні квадратично спадаючого до енер- 


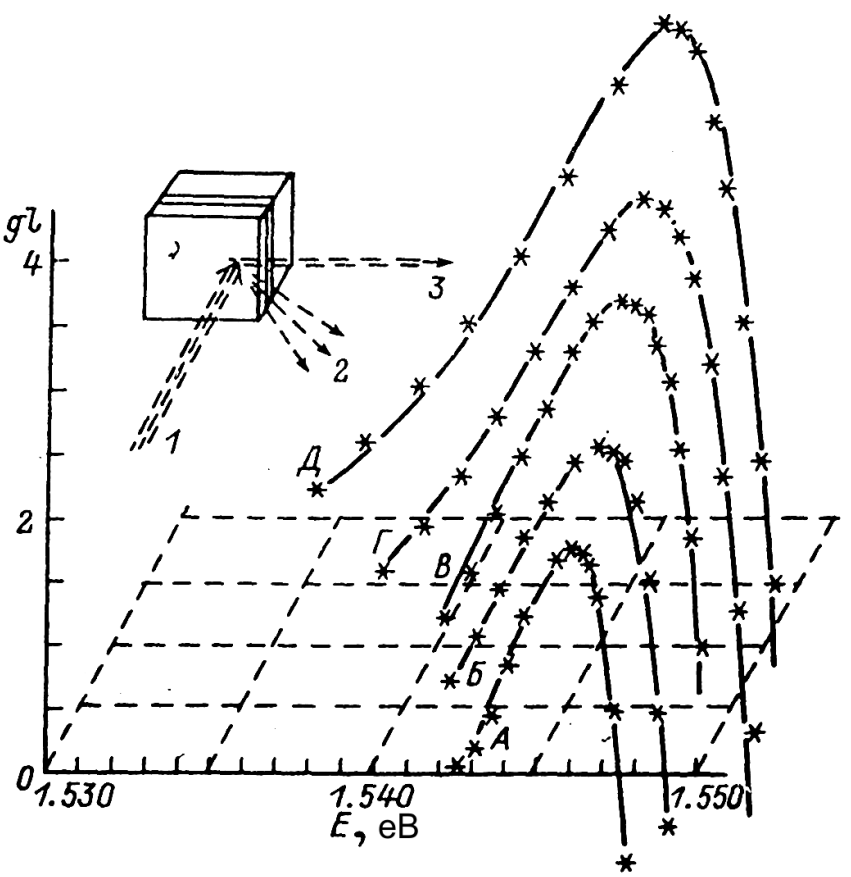

Рис. 8. Спектри оптичного підсилення надгратки $\mathrm{GaAs} / \mathrm{Al}_{0,35} \mathrm{Ga}_{0,65} \mathrm{As}$ при різних густинах збуджуючого випромінювання $L$. Точки - експеримент $(T=4,2 \mathrm{~K}$, $l=100$ мкм $),$ суцільні криві - розрахунок. $L\left(\mathrm{MBт} / \mathrm{cm}^{2}\right)$ : $a-0,2 ; \sigma-0,44 ; \quad$ в $-0,76 ;$ г $-1,68 ; \partial-4$. На вставці геометрія експерименту: 1 - лазерний промінь, 2 - спонтанне випромінювання, 3 - стимульоване випромінювання

гії Фермі затухання електронно-діркових станів $\Gamma=$ $\Gamma_{0}\left(1-k / k_{\mathrm{F}}\right)^{2}[16,17]$. Ймовірність випромінювання фотонів з енергією $E$ внаслідок розширення станів 3 енергією $E^{\prime}$ апроксимувалася нормалізованим лоренціаном $D\left(E, E^{\prime}\right)=(2 \pi)^{-1} \Gamma\left(E^{\prime}\right) /\left[\left(E-E^{\prime}\right)^{2}+\Gamma^{2}\left(E^{\prime}\right) / 4\right]$, який при $E^{\prime}>E_{\mathrm{F}}$ перетворюється в $\delta$-функцію. Результуючий спектр ОП $g(E)$ розраховувався шляхом згортки нерозширеного спектра підсилення $g^{\prime}(E)$ з лоренціаном $D\left(E, E^{\prime}\right)[18,19]$ :

$g(E)=\int_{E_{g}}^{\infty} g^{\prime}\left(E^{\prime}\right) D\left(E, E^{\prime}\right) d E^{\prime}$

де $E_{g}$ - ширина перенормованої забороненої зони, $g^{\prime}(E)=A\left(f_{e}+f_{h}-1\right), A-$ константа, що практично не залежить від енергії, $f_{e}$ i $f_{h}$ - електронна та діркова функції заселеності.

Особливістю проведеного нами розрахунку є врахування розтікання електронно-діркової плазми у площині квантових ям 3 дрейфовою швидкістю $V_{\mathrm{D}}$ внаслідок дії на носії заряду сил, зумовлених градієнтом фермієвського тиску шляхом використання

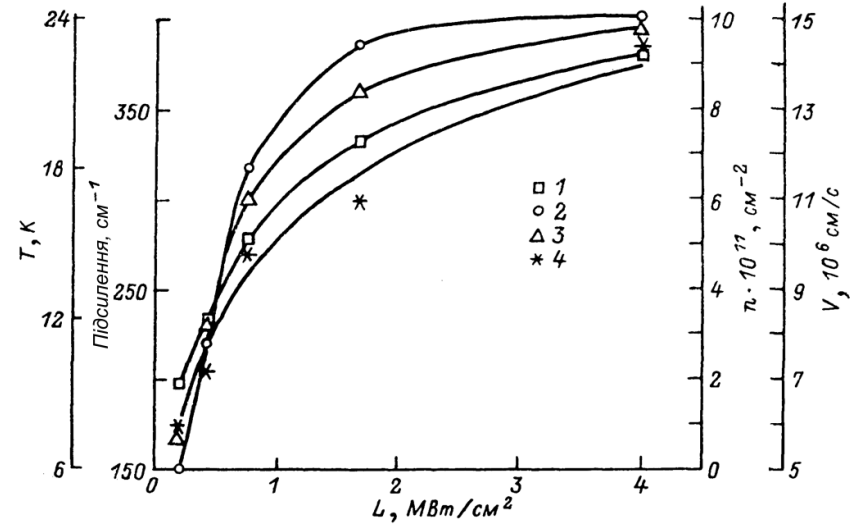

Рис. 9. Залежність від густини потужності збудження $L$ підгоночних параметрів: густини електронно-діркових пар $n(1)$, температури $T$ (2), дрейфової швидкості $V_{\mathrm{D}}(3)$, коефіцієнта оптичного підсилення $g(4)$, які використані при узгодженні експериментальних і теоретичних кривих $g l(E)$ (рис. 8)

зміщених функцій розподілу

$f_{e, h}=\frac{1}{\exp \left[\left(\frac{\hbar^{2}\left(\mathbf{k}+\mathbf{k}_{D_{e, h}}\right)^{2}}{2 m_{e, h}}-F_{e, h}\right) / k_{\mathrm{B}} T\right]+1}$

з усередненням за кутами між $\mathbf{k}$ i $\mathbf{k}_{D_{e, h}}$, де $\mathbf{k}_{D_{e, h}}=$ $m_{e, h} \mathbf{v}_{\mathrm{D}} / \hbar, F_{e, h}-$ квазірівні Фермі, що відраховуються від дна відповідних зон. Оскільки розглядаються прямі переходи, то зв'язок енергії з квазіімпульсом має при цьому вигляд $E=\hbar^{2} / k^{2} / 2 \mu+$ $E_{g}^{\prime}, \mu=m_{e} m_{h} /\left(m_{e}+m_{h}\right), m_{h}-$ маса важкої дірки. Квазірівні Фермі $F_{e, h}$ для даних конкретних умов можуть бути знайдені за формулою $F_{e, h}=$ $k_{\mathrm{B}} T \ln \left(\exp \left[\pi \hbar^{2} n / m_{e, h} k_{\mathrm{B}} T\right]-1\right)$, де $n-$ концентрація носіїв заряду, $T$ - ефективна температура в електронно-дірковій підсистемі.

$\mathrm{У}$ результаті розрахунку спектрів ОП за наведеними вище формулами при $\Gamma_{0}=1 \mathrm{мeB}$ і узгодження їх з отриманими на експерименті (рис. 8) були визначені параметри електронно-діркової плазми $T, g, n, V_{\mathrm{D}}$ при відповідних рівнях збудження (рис. 9).

Таким чином, при інтенсивних лазерних збудженнях у квантовій НГ GaAs/AlGa ${ }_{1-x}$ As формується двовимірна електронно-діркова плазма. Із аналізу форми спектрів ОП з урахуванням ефекту розтікання визначені такі параметри електронно-діркової плазми: концентрація нерівноважних носіїв, їх перегрів, а також дрейфова швидкість носіїв заряду, що виникає внаслідок фермієвського тиску. Значення останньої $\left(V_{\mathrm{D}}=10^{7} \mathrm{~cm} / \mathrm{c}\right)$ наближається до граничної швидкості перенесення електронів і дірок у твердому тілі. Величина коефіцієнта ОП для досліджува- 
ної НГ в 1,3 раза більше, ніж для гетероструктури $\mathrm{GaAs} / \mathrm{AlGa}_{1-x} \mathrm{As}$ при однакових рівнях збудження.

\section{5. Висновки}

Дослідження спектрів ФЛ з часовим розділенням НГ GaAs/AlAs різних типів (прямозонні, квазіпрямозонні, непрямозонні) в широкому інтервалі температур дозволили встановити особливості рекомбінаційних процесів, які протікають у таких структурах.

Зокрема у прямозонних НГ з шириною ям порядку радіуса екситона зразу ж після збудження спостерігаються вільні важкі та легкі екситони, а також перехід "легкі-важкі екситони". Для НГ-І з товщиною шарів GaAs, менших від радіуса екситона при низьких температурах $(T<70 \mathrm{~K})$ вільні екситони протягом $\sim 150$ пс локалізуються на неоднорідностях гетеромеж і надалі випромінюють у вигляді нової смуги ФЛ. У НГ з ще меншою товщиною квантових шарів випромінювання при низьких температурах зумовлене зв'язаними екситонами, часткова делокалізація яких починається тільки при підвищенні температури $(T \geq 80 \mathrm{~K})$. I, нарешті, в прямозонних НГ GaAs/AlAs 3 надтонкими шарами (НГ 9/4) випромінювання локалізованих екситонів спостерігається у всьому досліджуваному інтервалі температур.

Зменшення ширини ями значно прискорює затухання ФЛ, що може бути пояснене зростанням безвипромінювальних втрат.

Для НГ другого типу $(n=m<12$ моношарів) характерним є значний вплив флуктуацій товщини квантових шарів на релаксацію носіїв заряду, який зростає із зменшенням товщини шарів і зумовлює значне зменшення випромінювального часу життя екситонів. При високих рівнях збудження у квазіпрямозонних зразках формується електроннодіркова плазма, концентрація носіїв в якій більш ніж на порядок перевищує відповідне значення для об'ємних кристалів GaAs.

Дослідження спектрів спонтанного та стимульованого випромінювання електронно-діркової плазми в $\mathrm{HI} \mathrm{GaAs} / \mathrm{Al}_{x} \mathrm{Ga}_{1-x} \mathrm{As}$ дозволило розрахувати спектри коефіцієнта оптичного підсилення залежно від густини накачки в області нелінійних ефектів.

1. S. Nihonyanagi and Y. Kanemitsu, Appl. Phys. Lett. 85, 5721 (2004).

2. D.W. Wang and S. Das Sarma, Phys. Rev. B 64, 195313 (2001).

3. P. Denk and J.L. Pelouard, Phys. Rev. B 63, 041304 (2001).
4. Yu.E. Lozovik, O.L. Berman, and M. Willander, J. Phys: Condens. Matter. 14, 12457 (2002).

5. В.Й. Сугаков, УФЖ, 56, 492 (2011).

6. М.В. Бондар, М.С. Бродин, УФЖ 55, 1035 (2010).

7. Г.Ф. Караваев и др., Физика 53, 45 (2010).

8. V.G. Lytovchenko and D.V. Korbutyak, Surf. Sci. 170, 671 (1986).

9. Д.В. Корбутяк, В.Г. Литовченко, ФТТ 23, 1411 (1981).

10. М.С. Бродин, И.В. Блонский, М.И. Страшникова, Письма в ЖЭТФ 22, 516 (1975).

11. М.С. Бродин, И.В. Блонский, В.В. Тищенко, ФТТ 25, 1640 (1979).

12. Д.В. Корбутяк, С.Г. Крилюк, В.Г. Литовченко, УФЖ 43, 119 (1998).

13. L. Pavesi and M. Guzzi, J. Appl. Phys. 75, 4779 (1994).

14. Р. Балтрамеюнас, Е. Геразимас, Д.В. Корбутяк, Ю.В. Крюченко, Э. Куокштис, В.Г. Литовченко, ФТТ 30, 2020 (1988).

15. A. Forchel, H. Schweizer, and G. Mahler, Phys. Rev. Lett. 51, 501 (1983).

16. R.W. Martin and H.L. Störmev, Sol. St. Commn. 22, 523 (1977).

17. C. Klingshirn and H. Haug, Phys. Rev. B. 70, 315 (1981).

18. E. Zielinski, E., H. Schweizer, S. Hausser, R. Stuber, M.N. Pilkuhn, and G. Wiemann, IEEE J. Quant. Electr. QE-23, 969 (1987).

19. R. Cigolani, K. Ploog, A. Cingolani, C. Moro, and M. Ferrara, Phys. Rev. B. 42, 2893 (1990).

Одержано 01.07.11

ЛЮМИНЕСЦЕНТНЫЕ

СВОЙСТВА ПРИПОВЕРХНОСТНЫХ

ПОЛУПРОВОДНИКОВЫХ СЛОЕВ

И КВАНТОВЫХ СВЕРХРЕШЕТОК

В.Г. Литовченко, Д.В. Корбутлк

Р ез ю м е

Приведены новые результаты люминесцентных исследований квантовых сверхрешеток (CP) GaAs/AlAs I и II типа, а также границ раздела гетероструктур GaAs/AlAs с использованием импульсных (фемтосекундных) источников возбуждения. Проанализированы особенности кинетики фотолюминесценции $\mathrm{CP} \mathrm{GaAs} / \mathrm{AlAs}$ с разными ширинами квантовых ям (GaAs) и барьеров (AlAs). При высоких уровнях возбуждения в квазипрямозонных СР формируется электронно-дырочная плазма, концентрация носителей заряда в которой больше чем на порядок превышает соответствующее значение для объемных кристаллов GaAs. Исследование спектров спонтанного и стимулированного излучения электронно-дырочной плазмы в $\mathrm{CP} \mathrm{GaAs} / \mathrm{AlAs}$ позволило рассчитать спектры коэффициента оптического усиления в зависимости от плотности накачки в области нелинейных эффектов. 


\section{LUMINESCENT PROPERTIES OF NEAR-SURFACE SEMICONDICTIVE LAYERS AND QUANTUM SUPERLATTICES}

\author{
V.G. Lytovchenko, D.V. Korbutyak
}

V. Lashkaryov Institute of Semiconductor Physics, Nat. Acad. of Sci. of Ukraine

(41, Prosp. Nauky, Kyiv 03680, Ukraine;

e-mail: lvg@isp.kiev.ua,kdv45@isp.kiev.ua)

$\mathrm{S} \mathrm{u} \mathrm{m} \mathrm{m} \mathrm{a} \mathrm{r} \mathrm{y}$

The new results of studies of the GaAs/AlAs quantum superlattices (QSLs) of the I and II types and the interfaces of het- erostructures (surface effects) using the pulse (femtosecond) light excitation technique have been presented. The peculiarities of the photoluminescence relaxation of QSLs with various thicknesses of Q-layers (GaAs) and barriers (AlAs) are analyzed. It is demonstrated that, at a high excitation level, the electron-hole plasma appears in the quasidirect-gap QSLs, where the density of free carriers is by more than one order larger than that possible for the bulk of GaAs. By studying the spectra of spontaneous and stimulated emissions, we calculate the optical gain coefficient as a function of the pumping density for nonlinear effects. 